\title{
Validation of a Learning Object Review Instrument: Relationship between Ratings of Learning Objects and Actual Learning Outcomes
}

\author{
Yavuz Akpinar \\ Boga zici University, Department of Computer Education and \\ Educational Technology, Istanbul, Turkey
}

Akpinar@boun.edu.tr

\begin{abstract}
Growing interest in leaming objects (LOs) as a means of developing learning mat erials is leading to mainline LO evaluation methodologies using review instruments, such as evaluation rubrics, to suit various practical purposes. Such evaluation tools give evidence about the design and the value of the LOs, and studies performed with actual users can provide data against which these expectations of the effects of LOs on student achievements in practice can be set. This study presents a validation of a learning object review instrument (LORI) with student users $(n=507)$ of twenty-four LOs used in K-12 environments. The data collected through pre- and post-tests, teachers' and students' usability questionnaires, and the LORI revealed some interactions between those variables. However, the LORI ratings, and the usability assessments did not correlate with the leaming gains of students. Some implications of these findings are discussed.
\end{abstract}

Keywords: Learning objects, leaming outcome, LORI, validation.

\section{Introduction}

To meet diverse learning needs and to improve student learning, a variety of resources, often including digital media, are developed where the combination of the media and methods of use change with context and try to take account of student differences. New technologies have emerged to assist these objectives, and one method of designing and presenting computer based educational materials is that of learning objects (LOs), usually defined as any digital resource that can be reused to support learning (Wiley, 2000). Examples of such digital resources that can be employed with in instructional materials include images or photos, live data feeds, live or prerecorded video or audio snippets, text, animations, and web-delivered applications such as a Java applet, a blog, or a web page combining text, images and other media. Thus LO approaches can be wide-ranging and offer new possibilities to access and reuse online materials (Wiley, 2005).

Material published as part of this publication, either on-line or in print, is copyrighted by the Informing Science Institute. Permission to make digital or paper copy of part or all of these works for personal or classroomuse is granted without fee provided that the copies are not made or distributed for profit or commercial advantage AND that copies 1) bear this notice in full and 2) give the full citation on the first page. It is permissible to abstract these works solong as credit is given. To copy in all other cases orto republish or to post on a serveror to redistribute to lists requires specific permission and payment of a fee. Contact 0HPublisher@,InformingScience.org to request redistribution permission.
Online repositories storing large numbers of LOs, which different user groups (e.g. teachers, instructional designers, material producers, and learners) can access and employ in various contexts according to their needs, can, in principle, bring economy and variety into the educational process (Nurmi \& Jaakkola, 2006a). However, although LOs can provide stimulating opport unities to improve educational practices, to extend 
the use of digitaltechnologies in schools and to reduce the time required to prepare technology enhanced teaching, many associated problems and practical shortcomings can arise (Akpinar \& Simsek, 2007; Jonassen \& Churchill, 2004; Kay \& Knaack, 2007; Li, Nesbit \& Richards, 2006; Nurmi \& Jaakkola, 2005; Parrish, 2004; Strijker, 2004; Vuorikari, Manouselis, \& Duval, 2006). There is a lack of empirical evidence on the effectiveness of LOs, though this has not reduced the interest in the technique, and indeed it provides an incentive for further research.

Whilst the LO debate continues (Churchill, 2007; Cochrane, 2005; Friesen, 2005; Krauss \& Ally, 2005; Maceviciute \& Wilson, 2008; Merrill, 2001; Parrish, 2004; Polsani, 2003; Salas \& Ellis, 2006; Varlamis \& Apostolakis, 2006; Wiley, 2000), the effectiveness of LOs is likely to be limited if they do not conform to established design principles and have not been subjected to formative user testing (Li et al., 2006). A range of different evaluation approaches for such leaming resources exists, and Vuorikari et al. (2006) studied and analyzed a sample of thirteen evaluation approaches either currently applied to learning object reposit ories (LORs) or used as general quality guidelines for digital learning resources. These approaches were dist inguished in terms of:

(1) methodological characteristics focusing on the process or the product;

(2) the stage of the leaming resource lifecycle focusing on developmental guidelines or enduser evaluation ratings;

(3) the educational processes or optimization parts of the development lifecycle;

(4) the form of evaluation instruments used, e.g. questionnaires, a list of criteria or certification instruments;

(5) the audience as developers, evaluators, subject experts, teachers, or end users;

(6) the criteria or metrics engaged by the tools; and

(7) the characteristics of the environment in which evaluation approach is expected to be applied.

Also, a recent survey (T zikopoulos, Manouselis, \& Vuorikari, 2007) reported on 23 highlighted evaluation and rating approaches. Because there is such diversity in the goals and forms of LO evaluations, Dron, Boyle, and Mitchell (2002) and Vuorikari et al. (2006) suggest the use of tagged metadata for storing the results of such evaluations, not only not ing data on sharing and reusability, but summarizing the experience and achievements LO resources in use.

\section{Learning Object Evaluation Instruments}

The mainline LO evaluation methodologies use review instruments such as evaluation rubrics, of which the most cited is the Leaming Object Review Instrument (LORI) developed by Vargo, Nesbit, Belfer, and Archambault (2003) and improved by Nesbit and Li (2004). LORI 1.5 uses nine it ems with brief descriptive rubrics associated with each item. The items and what they measure may be outlined as:

(1) Content Quality: The LO content is free of error and presented without bias. Claims are supported by logical arguments, and presentations highlight significant ideas.

(2) Learning Goal Alignment: Appropriate learning goals are stated. The learning activities, content, and assessments provided by the LO align with the declared goals.

(3) Feedback and Adaptation: The LO provides feedback driven by differing learner inputs or learner modeling.

(4) Motivation: The LO content is relevant to the personal goals and interests of the intended learners.

(5) Presentation Design: The style of information design in the LO enables users to learn efficiently. The presentations of the LO minimize visual search; text and graphics are clear, concise and free of errors. Screen components do not interfere with learning goals.

(6) Interaction Usability: The user interface design implicitly informs learners about how to 
interact with the LO. Navigation through the LO is simple. The behavior of the user interface is consistent and predictable.

(7) Accessibility: The design of controls and presentation formats in the LO may accommodate learners with sensory and motor disabilities. The LO can be accessed through different electronic means including assistive and highly portable devices.

(8) Reusability: The LO is a stand-alone resource that can be readily transferred to different courses, learning designs, and contexts.

(9) Standards Compliance: The LO conforms to relevant international standards and specifications. Sufficient metadata is provided in tagged codes and made available to users.

LORI 1.5 uses a Likert-style five point response scale with the items ranging from low (1) to high (5). If an item is judged not relevant to the LO, or if the reviewer does not feel qualified to judge that criterion, then the reviewer may opt out of the it em by selecting "not applicable." But the convergent evaluation model used in the LORI is criticized by Kay and Knaack (2007), who note that it is usually limited by the small number of participants giving feedback, and its final evaluation may not be representative of what a larger population might observe or experience.

To review LOs for acceptance in one of the largest LO repositories, MERLOT (www.merlot.org), adopted many of the same criteria used by the LORI. The Merlot process employs both individual evaluation (peer review) and referral to standards for learning objects. The standards or guidelines are an attempt to help reviewers assess materials submitted by developers, and the criteria used by Merlot reviewers fall into three broad areas: The quality of content, the potential effect iveness as a teaching-learning tool, and the ease of use. The Merlot scale uses a continuum from one star denoting "material not worthy of use" to a five star rating representing "excellence all around." Like the LORI process, reviewers are taken from the subject discipline of the LO content. The Collaborative Learning Object Exchange (CLOE) of Canada has also built up a peer review process for LOs to be included in a provincial LO repository. This process closely follows the Merlot criteria but differs in the range and number of questions used. The Merlot criteria employ a set of more than 30 individual questions requiring detailed answers, while the CLOE criteria use 14 items. In brief, reviewers (i.e. instructional designers and subject matter experts) are asked to evaluate the LOs on the quality of their content, their effectiveness as a teaching tool, and their ease of use. Finally, Haughey and Muirhead (2005) proposed a further evaluation instrument, Learning Object Evaluation Instrument (LOEI), which was developed from the previous three instruments. The scales used in evaluating each LO component are not meant to provide comparisons, but to allow reviewers to assess the integrity, usability, leaming, design, and value focus of each learning object.

Although the LO repositories commonly use these review instruments, only a limited number of empirical studies have examined the learning outcomes and the instructional effectiveness of LOs. By using LO survey tools, Kay and Knaack $(2005,2007)$ examined the quality of LOs through content analysis of open-ended response questions based on principles of instructional design and perceived benefit under post-hoc structured cat egories. They evaluated 5 learning objects with 220 secondary school students, in grades 9-12, with 30 teachers. The evaluation data were collected after the sample used the LOs either as an introduction to the learning of concepts in the subject matter area or as support material to the teachers' activities. The data collection tools included interviews with teachers and two surveys collecting comments of students and teachers. The results showed that two-thirds of all students felt that LOs were beneficial, particularly when they had a motivating theme, visual supports, and interactivity. Also, both experienced and pre-service teachers confirmed the student reports. However, this study focused on perceived benefits of LOs rather than on the actual learning out comes resulting from the LO activities.

McCormick and Li (2006) also studied 770 teachers' views and experiences of using LOs in CELEBRATE (a research and development project dealing with LO development and implemen- 
tation funded by the European Union) through online surveys, routine data collected from the CELEBRATE portal, and semi-structured interviews in 40 schools in 6 different countries. The study showed a generally positive reaction to the use of LOs by the teachers as a support for teaching and learning. However, it was noted that teachers used the LOs in a variety of contrasting ways, and that they tended superimpose their own pedagogy, whatever the designed pedagogy of the LO. Hence it appeared that granularity and interoperability characteristics were significant in rating LOs as useful, particularly where they supported resource-based learning. However, both of the studies reviewed suggested the need for further evaluationtools, methods, and research to identify the actual effects of LOs on learning processes and outcomes.

In this respect, Nurmi and Jaakkola (2006b) conducted an experimental study using a pre-testpost-test design to evaluate the effectiveness of three LOs from three different subject areas, i.e. Mathematics, Finnish Language and Science. The LOs, tested with school children, were used in different instructional settings. The results revealed that in Mathematics and in Finnish students following traditional teaching conditions achieved slightly better results on subject matter posttests and developed more learning gains than students following the LO conditions, though these differences were not statistically significant. Also, no significant differences were observed between the LO and the traditionalteaching condit ions with low and high prior knowledge students. In the Science LO study, students in the mixed condition, where both LO and laboratory activities were used together, significantly outperformed those in thetraditionalteaching condition. The study concluded that, to be successful, LOs require carefully designed learning environments and instructional arrangements around them.

In a design similarto the Nurmi and Jaakkola (2006b) study, Akpinar and Simsek (2007) tested 8 LOs, whose overall LORI scores varied from 30 to 36 out of a maximum of 45, with 180 school children in a pre-post test research design. The data analysis revealed that 7 of the LOs helped the sample students improve their pretest scores, but in one, the Horizontal Projectile Motion (HRM) LO for ninth grade students, the scores did not improve. It seemed that this detrimental effect may have stemmed from the fact that HRM is atopic in which many students have misconceptions (T ao \& Gunstone, 1999) that the LO was unable to correct.

\section{The Validation Study}

In the evaluation of LOs, interested participants include selected subject matter experts, designers, and the actual users of the materials. All can provide helpful information for LO developers and other users, and understanding the interactions between them is critical to the practical applications of LOs. The study reported in this paper set out to author interactive LOs (bearing in mind design principles of interface clarity, consistency of naming, and interactivity) and, against these, to validate a learning object review instrument (the LORI v1.5 by Nesbit and Li, 2004) with teacher and student users of the LOs in a variety of K-12 contexts. Further, and in particular, the following research questions were examined:

(1) Whether the reviewers' ratings of the LOs on the basis of individual LORI items and total LORI scores for each LO interact with (a) the scores of teachers answering the usability test, (b) the students' scores on the usability test, and (c) the learning out comes of the students measured by post- and pre-test differences.

(2) Whether learning out comes of the resulting LOs differ in terms of (a) their scores on the individual LORI criteria and (b) the overall LORI assessments.

\section{Sample}

The sample for the LO evaluation studies consisted of a total of 507 elementary and secondary school students and their 24 teachers. The students' grades varied from 4 (age of 11) to 10 (age of 
17). The twenty-four LOs, (one in Biology, three in Chemistry, three in Mathematics, three in Physics and fourteen in General Science) whose development procedure is given below, were studied by 24 groups. The group size varied between 15 and 54 students.

\section{Materials and Procedure}

To validate the LORI, a series of LOs were authored by 26 senior instructional design students at the beginning of the spring semester of 2007. These senior students were taking their BSc. degree in four years at the Department of Computer Education and Educational Technology. In their previous courses, the students had completed instructional design and development projects in computer based instruction (CBI) and all had programmed and produced CBI designs and materials. The students were also taking a courseware development and evaluation course and contributed to this study as part of that course. Specifically they were asked to be authors and to develop a series of LOs to facilitate learning in a unit they selected from K-12 contexts. The interactive and problem based LOs had to fulfill the following requirements (Akpinar \& Hartley, 1996):

- The designed LO components, and sharable content objects (SCOs) should be sequenced in a certain order so that the LOthey constitute forms a coherent scenario.

- The scenario must make sense for the target students and employ their previous knowledge to help them overcome learning difficulties.

- The SCOs must have particular tools to enhance interactivity by encouraging students to try out their ideas and allowing them to learn from their mistakes.

- The SCOs must have facilities to concretize the content and to respond to individual differences in knowledge and experience.

- The LO facilities and scenario must give clear objectives and feedback to students and motivate them through challenging tasks.

- The sequence of SCOs must move from concrete to abstract and draw on appropriate knowledge representations.

Following their LO initial design activities, the authors met under the supervision of the researcher to discuss their design feat ures and justify the screen components they proposed. The discussions focused on the rationalization of the SCOs in the LOs and their contribution to overcoming specified learning difficulties in the selected leaming tasks. During these meet ings, the LO authors discussed their design ideas with other students to receive their advice. Authors completed programming their LO specification using the MM Flash platform. All activities in a LO were designed and implemented in a way that they can work as a stand-alone application. Each activity with all its assets may be used independently, taken into a different application, or embedded into some other LOs or even SCOs. The LO authors exchanged the assets of each others' LOs (e.g. images, animations, counters) in implementation of LOs where appropriate. Each developed LO was then evaluated by at least 10 peer reviewers (other LO authors) and by the researcher using LORI 1.5. These raters' scores for a particular LO were then averaged for each item (i.e. theme) of the LORI.

To test whether the developed (and LORI reviewed) LOs were able to effect learning outcomes when used by thetarget pupils and to validatethe LORI in actual learning environments, a series of classroom tests were designed. First, each LO author developed two achievement tests as pretest and posttest, containing parallel items in order to examine the possible contribution of the LOs to student achievement. Then each LO author developed LO usability questionnaires: one for students and one for teachers. These investigated whether the implemented LO was easy to use and understand and asked (using numbers of items expressed in suitable language) whether stu- 
dents approved the screen design, the text and picture orient at ion, the interactive mechanisms, and the tools used in the LO. These questionnaires all Likert type scales. Those for elementary school students had three choices: disagree, neutral, and agree; the other student questionnaires had five choices: strongly disagree, disagree, neutral, agree, and strongly agree. Likewise the usability questionnaires for teachers contained five-point Likert type items seeking teachers' opinions on the screen components and instructional facilities of a particular LO.

Both the pre/post tests and the usability questionnaires were reviewed, corrected, and verified by the researcher, by an expert instructional designer, and by one of the appropriate peers. For the classroom applications of the LOs, local schools were contacted for their agreement to participate, and with this permission the LO authors administered the pretest s to the designated students. [T wo of the twenty-six LOs were not used because their content had already been used in trialing studies.]

The authors of the LOs demonstrated the LOs and explained to the class teachers how the LOs worked, and the teachers were told there should be minimalteacher intervention during the students' working with the LOs. The authors then installed their LOs into the computer labs of the schools where they explained to the students and their class teacher how the LOs were to be used in the study sessions. These introductions of the LOs took 10-20 minutes, and the students' and the teachers' questions were also answered. The students then started to work with the LOs.

Whilst the students studied an LO, the LO author and the class teacher monit ored students' work. All students studied the LOs individually. To enable interaction and active participation, each LO presented task activities for the students to accomplish using the tools available in the LO. For example, the LO about the separation of mixtures for seventh graders asked students to play the role of a chemist and to separate mixed substances by selecting and using the given tools, such as a strainer, ventilator, boiler, distiller, or burner. The students' progress, moving from onetask to the next, depended on their performance over the tasks. If mistakes were made, then system feedback enabled students to correct these errors before moving on to the next task The LOs also contained help features related to the activities. The students' study sessions for an LO took between 20 and 65 minutes. Only two studies were carried out in multiple sessions due to large number of participants in the classes, one of which had 33 students organized in two sessions, and another of which had 54 students organized in three sessions. Following the study with the LOs, the posttests and the usability questionnaires were administered to the students: In ten of the studies they were administered just after the LO study; in all others they were administered the next day. All the studies were completed within a two weeks time period. Table 1 presents a summary of the data.

Table 1: A summary statistics of the studies

\begin{tabular}{|c|c|c|c|c|c|c|c|c|c|c|}
\hline LO Content & Grade/Age & $\begin{array}{c}\text { \# of } \\
\text { Activity }\end{array}$ & $\begin{array}{l}\text { Overall } \\
\text { LORI } \\
\text { Score }\end{array}$ & $\begin{array}{l}\text { Teachers' } \\
\text { Usability } \\
\text { Test }\end{array}$ & $\begin{array}{c}\text { Students' } \\
\text { Usability } \\
\text { Test }\end{array}$ & $\begin{array}{c}\text { Post- } \\
\text { Pretest } \\
\text { Difference }\end{array}$ & $\begin{array}{l}\text { Sample } \\
\text { size }\end{array}$ & $\begin{array}{l}\text { Statistical } \\
\text { test }\end{array}$ & $\mathrm{p}$ & $\begin{array}{l}\text { Effect size } \\
\text { Cohen's d }\end{array}$ \\
\hline $\begin{array}{l}\text { Science } \\
\text { (Nutrition \& Its } \\
\text { Agents) }\end{array}$ & $5 / 12$ & 9 & 39.16 & 0.80 & 0.80 & 22.40 & 21 & $\mathrm{t}$ & $0.00 * *$ & 1.45 \\
\hline $\begin{array}{l}\text { Mathematics } \\
\text { (Functions) }\end{array}$ & $9 / 16$ & 26 & 34.44 & 0.81 & 0.80 & 21.93 & 22 & $\mathrm{t}$ & $0.00 * *$ & 1.31 \\
\hline $\begin{array}{l}\text { Science } \\
\text { (Separation of } \\
\text { Mixtures) }\end{array}$ & $7 / 14$ & 12 & 39.92 & 0.89 & 0.88 & 18.00 & 20 & $\mathrm{t}$ & $0.00 * *$ & 1.09 \\
\hline $\begin{array}{l}\text { Science } \\
\text { (H. Motion) }\end{array}$ & $7 / 14$ & 18 & 36.10 & 0.86 & 0.90 & 18.50 & 20 & $\mathrm{t}$ & $0.00 * *$ & 1.08 \\
\hline $\begin{array}{l}\text { Biology } \\
\text { (Animal Cell) }\end{array}$ & $9 / 16$ & 13 & 32.83 & 0.74 & 0.80 & 30.39 & 19 & $\mathrm{t}$ & $0.00 * *$ & 1.05 \\
\hline $\begin{array}{l}\text { Science } \\
\text { (Change in Matter) }\end{array}$ & $7 / 14$ & 7 & 29.86 & 0.60 & 0.55 & 14.21 & 19 & $\mathrm{t}$ & $0.00 * *$ & 1.02 \\
\hline
\end{tabular}




\begin{tabular}{|c|c|c|c|c|c|c|c|c|c|c|}
\hline LO Content & Grade/Age & $\begin{array}{c}\text { \# of } \\
\text { Activity }\end{array}$ & $\begin{array}{l}\text { Overall } \\
\text { LORI } \\
\text { Score }\end{array}$ & $\begin{array}{l}\text { Teachers' } \\
\text { Usability } \\
\text { Test }\end{array}$ & $\begin{array}{l}\text { Students' } \\
\text { Usability } \\
\text { Test }\end{array}$ & $\begin{array}{c}\text { Post- } \\
\text { Pretest } \\
\text { Difference }\end{array}$ & $\begin{array}{l}\text { Sample } \\
\text { size }\end{array}$ & $\begin{array}{l}\text { Statistical } \\
\text { test }\end{array}$ & $\mathrm{p}$ & $\begin{array}{l}\text { Effect size } \\
\text { Cohen's d }\end{array}$ \\
\hline $\begin{array}{l}\text { Mathematics } \\
\text { (Ratio) }\end{array}$ & $7 / 14$ & 12 & 34.38 & 0.65 & 0.65 & 11.25 & 24 & M.W.-U & $0.00 * *$ & 0.88 \\
\hline $\begin{array}{l}\text { Science } \\
\text { (Atoms) }\end{array}$ & $7 / 14$ & 10 & 37.58 & 0.80 & 0.89 & 18.89 & 18 & W & $0.03 *$ & 0.84 \\
\hline $\begin{array}{l}\text { Chemistry } \\
\text { (Reactions) }\end{array}$ & $9 / 16$ & 11 & 36.58 & 0.85 & 0.87 & 16.00 & 18 & $\mathrm{t}$ & $0.03 *$ & 0.76 \\
\hline $\begin{array}{l}\text { Science } \\
\text { (Fluid Pressure) }\end{array}$ & $7 / 14$ & 12 & 32.50 & 0.73 & 0.80 & 11.43 & 21 & $\mathrm{t}$ & $0.02 *$ & 0.74 \\
\hline $\begin{array}{l}\text { Phy sics } \\
\text { (Proj ectile Motion) }\end{array}$ & $10 / 17$ & 8 & 36.05 & 0.75 & 0.73 & 23.40 & 15 & $\mathrm{t}$ & $0.03 *$ & 0.70 \\
\hline $\begin{array}{l}\text { Science } \\
\text { (Animate and Life) }\end{array}$ & $6 / 13$ & 8 & 31.48 & 0.80 & 0.72 & 4.77 & 21 & $\mathrm{t}$ & 0.14 & 0.33 \\
\hline $\begin{array}{l}\text { Science } \\
\text { (Class. of Matters) }\end{array}$ & $4 / 11$ & 15 & 36.33 & 0.80 & 0.80 & 5.46 & 22 & $\mathrm{t}$ & 0.21 & 0.34 \\
\hline $\begin{array}{l}\text { Science } \\
\text { (Properties of } \\
\text { Lights) }\end{array}$ & $8 / 15$ & 10 & 37.42 & 0.80 & 0.67 & 5.50 & 16 & $\mathrm{t}$ & 0.22 & 0.35 \\
\hline $\begin{array}{l}\text { Science } \\
\text { (Force) }\end{array}$ & $6 / 13$ & 8 & 34.78 & 0.84 & 0.83 & 6.36 & 22 & $\mathrm{t}$ & 0.22 & 0.34 \\
\hline $\begin{array}{l}\text { Science } \\
\text { (Electricity) }\end{array}$ & $6 / 13$ & 9 & 37.00 & 0.87 & 0.67 & -3.58 & 54 & $\mathrm{t}$ & 0.23 & -0.20 \\
\hline $\begin{array}{l}\text { Chemistry } \\
\text { (Gases) }\end{array}$ & $10 / 17$ & 10 & 31.74 & 0.80 & 0.73 & 11.60 & 18 & W & 0.28 & 0.36 \\
\hline $\begin{array}{l}\text { Science } \\
\text { (Pressure) }\end{array}$ & $7 / 14$ & 13 & 36.64 & 0.80 & 0.70 & 5.00 & 20 & $\mathrm{t}$ & 0.28 & 0.30 \\
\hline $\begin{array}{l}\text { Phy sics } \\
\text { (Expansion) }\end{array}$ & $9 / 16$ & 6 & 28.41 & 0.60 & 0.67 & 3.14 & 17 & $\mathrm{t}$ & 0.38 & 0.13 \\
\hline $\begin{array}{l}\text { Mathematics } \\
\text { (Circles) }\end{array}$ & $7 / 14$ & 8 & 34.57 & 0.80 & 0.80 & 2.43 & 33 & $\mathrm{t}$ & 0.63 & 0.08 \\
\hline $\begin{array}{l}\text { Chemistry } \\
\text { (Solutions) }\end{array}$ & $9 / 16$ & 7 & 31.05 & 0.93 & 0.85 & 5.50 & 15 & $\mathrm{t}$ & 0.68 & 0.16 \\
\hline $\begin{array}{l}\text { Science } \\
\text { (Torque \& Bal- } \\
\text { ance) }\end{array}$ & $10 / 17$ & 8 & 34.00 & 0.69 & 0.65 & -1.33 & 15 & $\mathrm{t}$ & 0.80 & -0.10 \\
\hline $\begin{array}{l}\text { Phy sics } \\
\text { (Heat\& Tempera- } \\
\text { ture) }\end{array}$ & $9 / 16$ & 11 & 29.79 & 0.60 & 0.83 & -1.20 & 17 & W & 0.85 & -0.05 \\
\hline $\begin{array}{l}\text { Science } \\
\text { (Circuits \& Con- } \\
\text { ductors) }\end{array}$ & $6 / 13$ & 10 & 37.80 & 0.80 & 0.80 & 1.00 & 20 & $\mathrm{t}$ & 0.80 & 0.04 \\
\hline
\end{tabular}

\section{Data Analysis and Results}

The data collected through the pre-tests, the post-tests, and the usability tests for both teachers and students were coded and analyzed statistically: The average and total LORI scores were obtained from the reviewers' rat ings, the pre-test and post-test student scores were calculated, and the post-test and the pre-test difference constituted the students' achievement indicat or. Further, the total usability scores for a teacher's usability assessments and students' usability assessments for each LO were calculated from their responses to the usability questionnaires. Because of the differences in it em numbers and rating classes, the responses to the questionnaires were first graded under the student group, and then their average scores were proportionately divided to convert each result into a shared metric between 0 (low) and 1 (high). The data obtained for each variable were then checked for normality. When the data distribution for variables showed normality, parametric statistical test s were employed, otherwise non-parametric tests were used. Note was also taken of whether the compared groups were independent (e.g. student and teacher usability evaluations) or correlated (e.g. the student groups on pre- and post-test measures). 


\section{Interaction between the LORI and the Study Variables}

To test whether the reviewers' ratings of the LOs (on the basis of individual LORI items and total LORI scores for each LO) were related to (a) teacher usability data, (b) students usability data, and (c) post and pre test achievement differences, a series of correlations (Spearman's rho) were undertaken (see Table 2). [The ninth item of the LORI, was about compliance of the LOs to the technical standards; the reviewers agree these conditions were fulfilled and this item is not included in this analysis.] These analyses can be summarized as follows:

i. The correlation of the teachers' usability ratings for the LOs with those of the students was statistically significant $(\mathrm{p}<0.01)$.

ii. The correlations of the ratings of Items 1 to 8 of the LORI and the total LORI were all significantly inter-correlated. ( $\mathrm{p}<0.01$ for all correlations).

iii. The teacher usability test scores for the LOs significantly correlated with LORI items of Content Quality $(\mathrm{p}<0.01)$, Learning Goal Alignment, Feedback and Adaptation, Interaction Usability $(\mathrm{p}<0.01)$, Accessibility, Reusability, and overall LORI scores of the LOs $(\mathrm{p}<$ $0.01)$, as well as with the students usability assessment scores $(\mathrm{p}<0.01)$.

iv. However, although in general the teacher and students' LOs usability rat ings achieved significant correlations (see (i)), the students' LO usability ratings did not achieve statistical significance with the LORI it ems shown in (iii).

v. The student post-pre test differences did not significantly correlate with any items of the LORI or the two types of usability tests.

Table 2: The correlation matrix

\begin{tabular}{|c|c|c|c|c|c|c|c|c|c|c|c|}
\hline & 12 & 3 & 4 & 5 & 6 & 7 & 8 & 9 & 10 & 11 & 12 \\
\hline 1. Teacher usability test & $-.56^{* \pi}$ & .12 & $.56^{* \pi}$ & $.51^{*}$ & $.41^{*}$ & .36 & .37 & $.54^{* \pi}$ & $.49^{*}$ & $.49^{*}$ & $.52^{* \pi}$ \\
\hline 2. Student usability test & - & .32 & .27 & .20 & .11 & .10 & .27 & .30 & .34 & .25 & .29 \\
\hline 3. Post-Pre test difference & & - & .21 & .04 & -.03 & .01 & .00 & -.02 & .01 & .15 & .07 \\
\hline 4. LORI_Item 1 & & & - & $.86^{* *}$ & $.69^{* *}$ & $.77^{* k}$ & $.76^{* *}$ & $.86^{* *}$ & $.76^{* *}$ & $.85^{* *}$ & $.87^{* *}$ \\
\hline 5. LORI_Item 2 & & & & - & $.78^{* *}$ & $.79^{* *}$ & $.82^{* *}$ & $.85^{* *}$ & $.85^{\text {** }}$ & $.91^{* *}$ & $.92^{* *}$ \\
\hline 6. LORI_Item 3 & & & & & - & $.76^{* *}$ & $.72^{* *}$ & $.60^{* *}$ & $.61^{* *}$ & $.62^{* *}$ & $.74^{* *}$ \\
\hline 7. LORI_Item 4 & & & & & & - & $.81^{* *}$ & $.77^{* \star}$ & $.71^{* *}$ & $.73^{* *}$ & $.85^{* *}$ \\
\hline 8. LORI_Item 5 & & & & & & & - & $.89^{* *}$ & $.85^{* *}$ & $.80^{* *}$ & $.94^{* *}$ \\
\hline 9. LORI_Item 6 & & & & & & & & - & $.91^{\text {* }}$ & $.87^{\text {** }}$ & $.94^{* *}$ \\
\hline 10. LORI_Item 7 & & & & & & & & & - & $.91^{* k}$ & $.94^{* *}$ \\
\hline 11. LORI_Item 8 & & & & & & & & & & - & $.92^{* *}$ \\
\hline 12. LORI_Total & & & & & & & & & & & - \\
\hline
\end{tabular}

\section{Quality Differences between the Learning Object Groups}

In the second part of the analysis, the twenty-four LOs were grouped depending on whetherthe students using that LO achieved significant learning benefits or not as measured by post-pre test differences. To confirm this grouping, Cohen's $d$ effect size measure forthe post and pre tests differences was also used; in that measure, the effect size 0.50 indicat es a medium and over 0.80 a large effect size (Cohen, 1992). Then a series of both $t$ and Mann-Whitney, and Willcoxon test $s$ were conducted (see Table 1) to test whether the two groups of LOs differed statistically in terms of their scores on the LORI items, and overall LORI scores. The two groups of LOs significantly differed $(U=31 ; Z=-2.37 ; p<0.05)$ only on "feedback and adaptation" properties, the LORI item 
3 , with the LO group gaining significant post-pre tests differences having higher mean LORI scores (see Table 3). There was a similar marked difference (not statistically significant) on the Presentation Design item. However the LO groups did not show marked differences on properties measured by the other items of the LORI, nor in the overall LORI scores.

Table 3: LORI item scores for the two groups of LOs

\begin{tabular}{|c|c|c|c|c|}
\hline \multirow[t]{2}{*}{ LORI Items } & \multicolumn{2}{|c|}{$\begin{array}{l}\text { LOs did not create significant } \\
\text { change }(n=13)\end{array}$} & \multicolumn{2}{|c|}{$\begin{array}{l}\text { LOs created significant } \\
\text { change }(n=11)\end{array}$} \\
\hline & Mean & Std. Dev. & Mean & Std. Dev. \\
\hline $\begin{array}{l}\text { 1. Content Quality: Veracity, accuracy, balanced presentation of } \\
\text { ideas, and appropriate level of detail }\end{array}$ & 3.70 & 0.44 & 3.94 & 0.47 \\
\hline $\begin{array}{l}\text { 2. Learning Goal Alignment: Alignment among learning goals, } \\
\text { activities, assessments, and learner characteristics }\end{array}$ & 3.68 & 0.45 & 3.84 & 0.42 \\
\hline $\begin{array}{l}\text { 3. Feedback and Adaptation: Adaptive content or feedback } \\
\text { driven by differential learner input or learner modeling }\end{array}$ & 3.39 & 0.46 & 3.75 & 0.32 \\
\hline $\begin{array}{l}\text { 4. Motivation: Ability to motivate and interest an identified } \\
\text { population of learners }\end{array}$ & 3.62 & 0.51 & 3.77 & 0.35 \\
\hline $\begin{array}{l}\text { 5. Presentation Design: Design of visual\& auditory information } \\
\text { for enhanced learning and efficientmental processing }\end{array}$ & 3.62 & 0.49 & 3.89 & 0.57 \\
\hline $\begin{array}{l}\text { 6. Interaction Usability: Ease of navigation, predictability of the } \\
\text { user interface, and quality of the interface help features }\end{array}$ & 3.68 & 0.36 & 3.72 & 0.53 \\
\hline $\begin{array}{l}\text { 7. Accessibility: Design of controls and presentation formats to } \\
\text { accommodate disabled and mobile learners }\end{array}$ & 3.57 & 029 & 3.69 & 0.38 \\
\hline $\begin{array}{l}\text { 8. Reusability: Ability to use in vary ing learning contexts and } \\
\text { with learners from differing backgrounds }\end{array}$ & 3.66 & 0.37 & 3.79 & 0.31 \\
\hline $\begin{array}{l}\text { 9. Standards Compliance: Adherence to international standards } \\
\text { and specifications }\end{array}$ & 5.00 & 0.00 & 5.00 & 0.00 \\
\hline Overall LORI score & 33.92 & 3.13 & 35.40 & 2.99 \\
\hline
\end{tabular}

\section{Discussion and Conclusions}

Approximately half of the LOs showed statistically significant differences in helping students to improve learning in the units that the LOs covered; and the differences between the post and the pre test scores in twenty-one LOs were positive (see Table 1). There were negative post-pre test score differences in three LOs, and three of the four lowest performing LOs on this criterion had (with one exception) the lowest ratings on usability from teachers and students. The relationship between the LORI scores of the LOs and the amount of improvement in learning through the LOs (measured through the pre and post tests) were examined through correlation studies. The postpre test score differences did not correlate significantly with the teachers' or the students' usability evaluation of the LOs, and the reviewers' ratings of the LOs in terms of both individual items of the LORI as well as the overall LORI scores for each LO. However, the two groups of LOs (differing in their support of significant post pretest leaming) showed similar differences on the feedback and adaptation features of the LOs as shown in the LORI ratings (see Table 3) but only on this feat ure. Finally, the first eight items of the LORI and the total LORI scores for the LOs inter-correlated highly $(\mathrm{p}<0.01)$ with each other, confirming the high internal consistency of the LORI.

Bearing in mind the relatively small numbers of users of each LO, the data from this study must be treated with due caution. However, it seems clear that LORI rubric based assessments are not sufficient in predicting significant learning outcomes of users. Squires and Preece (1999) agree with this conclusion, which turns attention to the description and use of metadatatags for LOs. The general findings of the study support recommendations by Dron et al. (2002) and Vuorikari 
et al. (2006) that the controversial issue of tagging LOs should be re-considered and, as it is worth noting (from this study), that although the teachers' usability rat ings correlated (in general) with the LORI ratings, the usability measures themselves also did not correlate significantly with the learning improvement scores. It seems then that tags should include the result or commentary of the LO applications linking to students' performance improvement, otherwise the LO repositories will be likely to end up offering unreliable guidance for students and may give uncertainties and problems for classroom teachers making selections for their students.

However, this study used LOs which were judged to be well designed under the LORI criteria and which also achieved high and consistent ratings on usability measures from teachers and students. But, although generally showing positive benefits and significant learning benefits in half of the LOs, the students' achievements were uneven. This directs attention to the modes of use of the LOs and the learning process itself. This study used the LOs in the fashion of self-directed explorat ory study, with little input or interaction from the supervising teachers. Although providing useful information for the study, this decision may have been unwise particularly in the light of the science results of the Nurmi and Jaakkola (2006b) research in which using LOs and laboratory studies together allowed those groups to significantly outperform other groups. Further work should give more attention to design feat ures (in which rubrics could be useful) in relation to the pedagogies to be followed and to the different research design, including control groups design.

Research looking more closely at student actions and the learning process it self could throw some light on the relations of performance to the rubric criteria.

The two groups of LOs were different in some ways: First, the group consist ing of LOs that created significant learning output has a greater number of activities in average (12.50 versus 9.50) than the other group of LOs. Second, as the analysis demonstrated, they have better feedback and adaptation facilities; thetype of feedback given by those LOs took differential learner inputs more into account. Third, they seem to have better quality design of visual and auditory information for enhanced learning and efficient mental processing than the other group of LOs. Further work may increase the number of activities in those LOs and may investigate effects of the activities with adaptive feedback. In addition, those LOs which do not seem to promote learning effectively may be revised in a guided manner and/ortried under a different study scheme. In these ways LORI type design criteria can be adapted and related to support pedagogies and learning contexts. Including such summary data within tagging schemes should allow the flexibility and reusability features of LOs to be more clearly demonstrated.

\section{Acknowledgements}

The author thanks both the anonymous reviewers, the LO authors, and the teachers and the students for participating in this research.

\section{References}

Akpinar, Y., \& Hartley, J. R. (1996). Designing interactive learning environments. Journal of Computer Assisted Learning, 12(1), 33-46.

Akpinar, Y., \& Simsek, H. (2007). Should K-12 teachers develop learning objects? Evidence from the field with K-12 students. International Journal of Instructional Technology and Distance Learning, 4(3), 31-44. Retrieved 02 June 2008 from www.itdl.org/Journal/Mar 07/Mar 07.pdf

Churchill, D. (2007). Towards a useful classi fication of learning objects. Educational Technology Research and Development, 55(5), 479-497.

Cochrane, T. (2005). Interactive quicktime: Developing and evaluating multimedia learning objects to enhance both face-to-face and distance e-l earning environments. Interdisciplinary Journal of Knowledge 
and Learning Objects, 1, 33-54. Retrieved June 02, 2008, from

http://www.ijklo.org/Volume1/v1p033-054Cochrane.pdf

Cohen, J. (1992) A power primer. Psychological Bulletin, 112(1), 155-159.

Dron, J., Boyle, C., \& Mitchell, R. (2002). Evaluating assessment using n dimensional filtering. In Proceedings of the World Conference on E-Learning in Corporate, Government, Healthcare, and Higher Education. Montreal, Canada, October 15-19. pp. 268-274. Norfolk, VA, AACE Publication.

Friesen, N. (2005). Interoperability and learning objects: An overview of e-learning standardization. Interdisciplinary Journal of Knowledge and Learning Objects, 1, 23-31. Retrieved June 02, 2008, from http://ijklo.org/Volume1/v1p023-031Friesen.pdf

Haughey M., \& Muirhead, B. (2005). Evaluating learning objects for schools. The e-Journal of Instructional Science and Technology. 8(1), Article3. Retrieved at 15 March 2008 from http://www.usq.edu.au/electpub/e-jist/docs/vol8 no1/fullpapers/Haughey Muirhead.pdf

Jonassen, Z. D., \& Churchill, D. (2004). Is there a learning orientation in learning objects? International Journal on E-Learning, 3(2), 32-41.

Kay, R., \& Knaack, L. (2005). Developing learning objects for secondary school students: A multicomponent model. Interdisciplinary Journal of Knowledge and Learning Objects, 1, 229-254. Retrieved June 02, 2008, from http://www.ijklo.org/Volume1/v1p229-254Kay Knaack.pdf

Kay, R., \& Knaack, L. (2007). Evaluating the learning in learning objects. Open Learning: The Journal of Open and Distance Learning, 22(1), 5-28.

Krauss, F., \& Ally, M. (2005). A study of the design and evaluation of a learning object and implications for content development. Interdisciplinary Journal of Knowledge and Learning Objects, 1, 1-22. Retrieved June 02, 2008, from http://ijklo.org/Volume1/v1p001-022Krauss.pdf

Li, J. Z, Nesbit, J. C., \& Richards, G. (2006). Evaluating learning objects across boundaries: The semantics of localization. Journal of Distance Education Technologies, 4(1), 17-30.

Maceviciute, E., \& Wilson T. D. (2008). Evaluation of learning objects from the user's perspective: The case of the EURIDICE Service. Interdisciplinary Journal of E-Learning and Learning Objects, 4, 8395. Retrieved June 02, 2008, from http://www.ijklo.org/Volume4/IJELLOv4p083095Maceviciute501.pdf

McCormick, R. \& Li, N. (2006). An evaluation of European learning objects in use. Learning, Media and Technology, 31(3), 213-231.

Merrill, M. D. (2001). Knowledge objects and mental models. In D. A. Wiley (Ed.), The instructional use of learning objects. Retrieved 02 June 2008 from http://www.reusability.org/read/chapters/merrill.doc

Nesbit, J. C., \& Li, J. (2004). Web-based tools for learning object evaluation. Proceedings of the International Conference on Education and Information Systems: Technologies and Applications, 2, 334-339.

Nurmi, S., \& Jaakkola, T. (2005). Problems underlying the learning object approach. International Journal of Instructional Technology and Distance Learning, 2(11), 61-66. Retrieved 02 June 2008 from www.itdl.org/Journal/Nov 05

Nurmi, S., \& Jaakkola, T. (2006a). Effectiven ess of learning objects in various instructional settings. Learning, Media and Technology, 31(3), 233-247.

Nurmi, S., \& Jaakkola, T. (2006b). Promises and pitfalls of learning objects. Learning, Media and Technology, 31(3), 269-285.

Parrish, P. E. (2004). The trouble with learning objects. Educational Technology, Research \& Development, 52(1), 49-67.

Polsani, P. R. (2003). Use and abuse of reus able learning objects. Journal of Digital Information, 3(4) Article No. 164, Retrieved June 02, 2008, from http://jodi.tamu.edu/Articles/v03/i04/Polsani/ 
Salas, K., \& Ellis, L. (2006). The development and implementation of learning objects in a higher education setting. Interdisciplinary Journal of Knowledge and Learning Objects, 2, 1-22. Retrieved June 02, 2008, from http://iiklo.org/Volume2/v2p001-022deSalas.pdf

Squires, D., \& Preece, J. (1999). Predicting quality in educational software: Evaluating for learning, usability and the synergy between them. Interacting with Computers, 11(5), 467-483.

Strijker, A. (2004). Reuse of learning objects in context: Human and technical issues. Enschede, PrintPartners Ipskamp.

Tao, P. K., \& Gunstone R. F. (1999). The process of conceptual change in force and motion during computer-supported physics instruction. Journal of Research in Science Teaching, 36(7), 859-882.

Tzikopoulos, A., Manouselis, N., \& Vuorikari, R. (2007). An overview of learning object repositories. In P. Northrup (Ed.), Learning objects for instruction: Design and evaluation (pp. 29-55). Hershey, PA: Idea Group Publishing.

Vargo, J., Nesbit, J. C., Belfer, K., \& Archambault, A. (2003). Learning object evaluation: Computermediated collaboration and inter-rater reliability. International Journal of Computers and Applications, 25(3), 1-8.

Varlamis, I., \& Apostolakis, I. (2006). The present and future of standards for e-l earning technologies. Interdisciplinary Journal of Knowledge and Learning Objects, 2, 59-76. Retrieved June 02, 2008, from http://ijklo.org/Volume2/v2p059-076Varlamis.pdf

Vuorikari, R., Manouselis, N., \& Duval, E. (2006). Using metadata for storing, sharing and reusing evaluations for social recommendations. In Go, D. H. \& Foo, S. (Eds.), Social Information retrieval systems: Emerging technologies and applications for searching the web effectively. pp.165-178. Hershey, PA: Idea Group Publishing.

Wiley, D. A. (2000). Connecting learning objects to instructional design theory: A definition, a metaphor, and a taxonomy. In D. A. Wiley (Ed.), The instructional use of learning objects: Retrieved 02 June 2008 from http://reusability.org/read/chapters/wiley.doc

Wiley, D. A. (2005). Learning objects in public and higher education. In J. M. Spector, C. Ohrazda, A. van Schaack, \& D. A. Wiley (Eds.), Innovations in instructional technolog, (pp. 1-10). Mahwah, NJ: Lawrence Erlbaum.

\section{Biography}

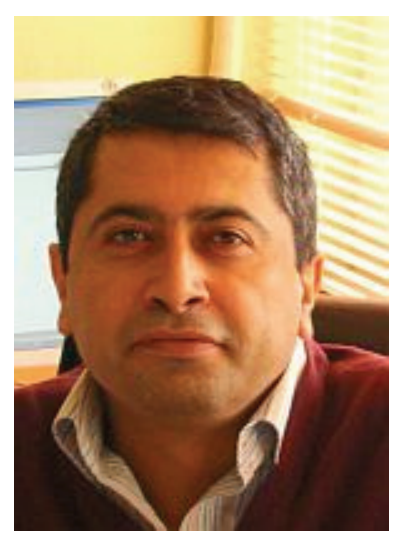

Yavuz Akpinar is an associate professor at Bogazici University, Department of Computer Education and Educational Technology. His research interests are in interactive leaming environments design, human computer interaction, simulations in leaming, authoring systems for soft ware design, educational testing, designing and evaluating multimedia and hypermedia in education and training, distance education, learning object and e-learning design, and learning management systems. 